\title{
How electoral designers fail: The contextual straightjackets of reform
}

Kenneth Bunker, kabunker@gmail.com

UDP/Observatorio Político Electoral

\begin{abstract}
When electoral designers conduct reform, they work within given frameworks to meet certain objectives. One of the most common goals is to produce a system which outputs results in favor of the commissioners. While designers are normally able to a generate system-level impacts, they sometimes fail to secure electoral spoils for their parties. How does this happen? This article proposes the cube root law and the seat product model to identify designers' underlying objectives and explore the contexts under which they fail to meet them. It uses data from eight legislative elections in Chile (1989-2017) to show how two different designers impacted patterns of representation and proportionality. It finds that while they both were successful in achieving system-level shifts in their desired directions, only one of them was able to benefit their commissioner. It suggests that designer that failed to produce spoils for his party was constrained by contextual straitjackets. Keywords: Electoral Designer; Cube Root Law; Seat Model Product; Party System; Electoral System.
\end{abstract}

Resumen: Cuando los diseñadores electorales llevan a cabo reformas, trabajan dentro de ciertos marcos para conseguir ciertos objetivos. Uno de los objetivos más comunes es producir resultados favorables para su partido. Mientras que normalmente son capaces de generar incentivos a nivel de sistema, a veces fallan en beneficiar a su partido. ¿Cómo sucede esto? Este artículo propone la ley de raíz cúbica y el modelo de producto de escaños para identificar los objetivos de los diseñadores y explorar los contextos en que fallan en conseguirlos. Utiliza datos de ocho elecciones legislativas de Chile (1989-2017) para mostrar cómo dos diseñadores diferentes impactaron patrones de representación y proporcionalidad. Encuentra que mientras ambos tuvieron éxito en forzar cambios a nivel de sistema en sus direcciones deseadas, solo uno pudo beneficiar a su partido. Sugiere que los diseñadores están limitados por camisas de fuerza contextuales. Palabras Clave: Diseñador Electoral; Ley de Raíz Cúbica; Modelo de Producto de Escaños; Sistema de Partidos; Sistema Electoral. 


\section{INTRODUCTION}

Electoral systems have a direct impact on party systems (Duverger 1954). The rules of the game define the strategies that the players adopt (Cox 1997). But even identical electoral arrangements can have significantly different effects on the partisan landscape (Taagepera and Grofman 2003). It is thus crucial to look at the process that takes place behind the adoption of electoral systems to fully understand the interaction between electoral institutions and party landscapes (Reynolds et. al 2006). In this vein, it is electoral designers who are in charge of engineering the particular sets of laws (Norris 2004). Normally they are the ones responsible for ensuring that the electoral reforms will work to fulfill a series of predetermined objectives set by their commissioners.

Conventional wisdom is that electoral systems are easy to change, and that electoral designers have full control over the process. However, as described to some length in the following section, neither is necessarily true. Indeed, electoral reform only seems to come to fruition under certain conditions, such as when the sitting government can benefit from a new set of laws, when the current arrangement shows critical failure, or when an unusually particular combination of contingent factors comes together (Jacobs and Otjes 2015: 288-289). And even when the conditions are right, electoral systems "are born kicking and screaming into the world out of a messy, incremental compromise between contending factions battling for survival" (Norris 1995: 4).

This article focuses on the process of electoral system design. It uses the case of Chile, a democracy with two major alterations to its electoral rules in the recent past, to illustrate how electoral designers can fail to meet their objectives. Because the two reforms sought structurally equal objectives (modifying the assembly size and the district magnitude), they can be compared against the same standards. But because they were conducted under significantly different contexts (one under dictatorship and one under democracy), they can be contrasted in terms of their process. This article shows that the two electoral designers fared differently. While the authoritarian designers were successful in guaranteeing electoral success for their commissioners, the democratic designers were not. 
This is an interesting puzzle. Why do electoral designers fail to secure electoral spoils in favor of their party? In the case of Chile, why did electoral designers commissioned by a coalition with a relevant majority in Congress put forward a system that would later lead to their party's worst electoral outcome ever? This article suggests that electoral reform under democracy is naturally more constrained than electoral reform under dictatorship. Because authoritarian electoral reform can be done under the blanket of darkness, it is easier for designers to manipulate arrangements in their favor. And because democratic reform tends to take on a life of its own, generating ripples across the party system before it is even enacted, it is harder for designers to control the outcome of their own creation.

This is an important issue amidst the rise of electoral reforms. While some have argued that it remains overall rare, it has been found to be significantly increasing in some regions, such as in Latin America (Remmer 2008; Freidenberg and Dosek 2015). In some of these democracies, however, the debut of new electoral systems has produced adverse results for the designers' parties, like in the case of Chile (see Bunker 2018). This may explain why parties in other democracies have consistently refused to reform. It is thus important to understand why electoral designers fail. A deeper look into these cases may not only explain more about the more general process of electoral reform, but also more about the particular contexts under which designers hinder their own commissioners.

The remainder of this article is structured as follows. The next section reviews some theories of electoral system design and reform, such as the rational choice, institutionalist, and historical comparativist approaches. The third section turns to the case of Chile and focuses on two major alterations made to its electoral rules in its recent past, the first of which was designed by the right-wing dictatorship of Augusto Pinochet, and the latter of which was designed by the left-wing democratic government of Michelle Bachelet. The fourth section shows how designers fared differently in securing electoral spoils for their parties. The final sections conclude by discussing the reasons to why this happened and examining the overall utility of comparing electoral system design and reform. 


\section{ELECTORAL SYSTEM DESIGN AND REFORM}

All democracies necessarily function through elections. While they can be defined by many criteria (Dahl 1971), free and fair elections, where political parties contest and loose elections, is a definition that meets the basic requirement (Przeworski 1991). The set of rules that define who wins representation are, then, at the center of democracy (Lijphart 1984). Since electoral systems can favor or hinder specific parties, choosing the rules of the game is at the core of the process (Norris 2007). As such, who chooses electoral systems, how long they last, and why they are replaced, are central concerns. Accordingly, researcher has placed both electoral system design (Boix 1999; Negretto and Visconti 2018) and electoral system reform (Renwick 2010; Bowler and Donovan 2013) at center stage.

Electoral system design is different to electoral system reform. Implementing an electoral system for the first time is fundamentally different to altering the rules of an arrangement already in place. Indeed, Boix (1999: 621-622) contends that if the conditions for electoral competition are stable and the electoral system "serves" the interest of the incumbent party, electoral reform is improbable. However, when electoral competition is uncertain and the incumbent parties are threatened by losing shares of power, electoral reform becomes more likely. Thus, the decision to retain a given electoral system or replace it depends on a costbenefit analysis. Maintaining a FPTP system or replacing it with a PR arrangement depends on the expectations of the ruling party and its prospects of making electoral gains.

The above suggest that the adoption of a new electoral system is the product of a logical decision. However, Jacobs and Otjes (2015) contend that they can also come about through other means: either when the current electoral system fails to deliver on its original purpose, or when public opinion mobilizes in favor of change. These three approaches can be synthesized by the rational choice, the institutionalist and the historical comparativist schools of thought (see Leyenaar and Hazan 2011). Naturally, the adoption of a new electoral system can occur because of one or more of these reasons. Indeed, the likelihood of adopting a new system will become more likely if the incumbent party can benefit from an alternative arrangement, the incumbent system is failing, and public opinion is favorable to change. 
The rational choice approach, pioneered by Boix (1999), suggests that designers principally put their interest at the forefront. Indeed, electoral reform will only occur if the incumbent party can increase their vote share (Benoit 2004; Colomer 2004; Blais and Shugart 2008; Rahat 2008). For instance, if they see that the incumbent district borders produce distortions in favor of the opposition, they may become interested in rearranging the delimitations to better suit their interests. Reform is thus dependent on the strategic calculations of the elites who choose the electoral rules to fit their own ends of maximizing gains or minimizing losses. This approach can help explain the 1985 electoral reform in France, in which the shift to PR was prompted by the Socialist Party to cut potential losses (Renwick 2010).

The above, however, suggest that parties have substantive information. Yet, this is rarely the case. It is well documented that there are normally high levels of uncertainty in terms of potential electoral system impact (Taagepera and Shugart 1989; Colomer 2004), which makes a rational choice-based decision difficult (Andrews and Jackman 2005; Baldini 2011). In this context, an institutionalist approach can be more parsimonious in explaining why reform comes about, since it only contends that change becomes necessary when the incumbent system regularly produces systemic failures and anomalous outcomes (Shugart and Wattenberg 2001; Shugart 2008). For example, if a majoritarian system randomly produces 'wrong winners', parties will tend to seek a more just arrangement.

The third approach to understanding electoral system adoption is through a historical process scope, in which the demand for a new electoral system is placed at center stage. It essentially merges the two former approaches to render a clearer vision of the actual negotiations and structural conditions that lead to reform (Rahat 2008; Renwick 2010). This makes sense considering that rational judgments about the effects of specific electoral systems are not only difficult to make (Andrews and Jackman 2005; Baldini 2011) but are also the product of specific events (Reynolds et al. 2005). In this way, given that the process takes place at a semiconscious level, parties and politicians will only decide to conduct reform when it is seen as legitimate in the eyes of the voters (Blau 2008; Vowles 2008). 
Notwithstanding the above, designers and reformers normally attempt to push forward reform in certain ways in order to obtain specific results. Indeed, reforms are often categorized as either permissive or restrictive (Remmer 2008). While permissive reforms tend to lower the barriers of entrance, restrictive reforms seek to fortify them. Whether an electoral system has permissive or restrictive incentives will depend on the combination of the particular sets of rules (Lijphart and Grofman 1984). While in parliamentary settings they are simply related to the set of rules that govern general elections, in presidentialism they are normally related to the interaction of the sets of rules that regulate both executive and legislative elections (Shugart and Carey 1992; Mainwaring and Shugart 1997).

In the latter case, electoral designers can influence patterns of representation by regulating laws related to presidential elections (Horowitz 1990; Jones 1995), such as candidate provisions (Jones 1999) and term limits (Carey 1998), as well as by tapping into those related to legislative elections, such as district boundaries (Cain 1985; Winburn 2008), the way that ballots are designed and cast (Engstrom and Kernell 2005), and internal party regulations (Argersinger 1980; Masket 2007). Following in the tradition of Duverger (1954), Rae (1967), Riker (1982), and Lijphart (1994) argue that four core elements of electoral structures stand out as the most important determinants: the district magnitude, the size of the assembly, the electoral formula, and the electoral threshold.

It is important to note, however, that these core elements do not independently determine patterns of representation (see Colomer 2005). Instead, it is the interaction between electoral rules and social structures that define the shape and size of party systems. For example, Ordeshook and Shvetsova (1994) and Neto and Cox (1997) show that including both additive and multiplicative specifications is essential to properly explain party system fragmentation. More recent accounts further suggest that because levels of social heterogeneity tend to be stable over time (within democracies), they can be held constant, and it is ultimately the level of permissiveness (or restrictiveness) of electoral rules that determine party fragmentation levels (Clark and Golder 2006; Teorell and Lindstedt 2010). 
Thus, the relevant questions are all intrinsically related to the role of electoral system designers, their underlying motivations and their levels of success. For example, what are their objectives when designing a new electoral system? Are they reforming to correct fundamental distortions or are they reforming to produce electoral spoils in favor of their commissioners? And, if it is the latter, how much can they actually do to force an expansion or a contraction in the number of parties that compete in elections and win seats in the legislature? Does the simple adoption of permissive or restrictive electoral rules suffice to generate their objectives? Or, perhaps more importantly, under which contexts are electoral designers more likely to succeed and under which contexts are they more likely to fail?

\section{CASE SELECTION}

To answer these questions, this article follows the approach of Mainwaring (1999) for Brazil and Van der Kolk (2007) for the Netherlands and uses a single case (Chile) to identify the underlying objectives of electoral designers and assess their levels of success. Also, following Navia (2004), it does not only seek to explain what happened in Chile, but instead to understand how electoral designers make their choices, and how those choices can ultimately affect their commissioning parties. Furthermore, it seeks to inform the literature by reviewing the process of electoral reform, and by showing how the rational choice and institutional approaches can play a significant role in both explaining the adoption of electoral systems as well as in evaluating their effect on party system power distributions.

Chile is a useful case to look at because it has been through two major electoral reforms in the past thirty years (one in 1989 and one in 2015). The different objectives and contexts of these reforms can help explain the range of possibilities that designers face when engineering electoral rules, as well as help identify the scenarios under which they thrive. The two reforms differ in their objectives in that one of them sought to introduce restrictive incentives into the electoral system, while the other one sought to introduce permissive ones. They also differ in their contexts, in that one of the reforms took place under dictatorship and the other one took place under democracy — while the former was conducted under the blanket of darkness, the latter was conducted in a public multi-party system setting. 
However, the two reforms are sufficiently similar to be compared to each other. Indeed, both considered changes to the same set of core elements. While both the authoritarian and democratic electoral designers decided to maintain the electoral formula of the incumbent systems (d'Hondt), they both decided to amend the district magnitude and the assembly size. In contrast to other, more complex processes, the two reforms conducted in Chile, were remarkably proportional in opposite directions - the second reform essentially reversed the doings of the first. This substantially aids in the process of identifying what the designers' intentions were at the time of engineering the reforms and assessing the degree to which they were finally able to meet their expectations.

What makes both reforms remarkably exceptional is the effect they had on the designers' commissioners. While the reform conducted in dictatorship boosted the right-wing parties associated to the authoritarian regime, the reform conducted in democracy hindered the leftwing parties that pushed it through Congress. The next section briefly explains the origin of the reforms, discusses the objectives of the designers and lays out their expectations in terms of the effects that they most likely anticipated on patterns of representation and proportionality. The section after the next compares the results of both reforms in terms of their actual effect on the party system. It proposes the cube root law (following Taagepera 1972) and the seat product model (following Shugart and Taagepera 2017) as standards.

\section{ELECTORAL SYSTEM DESIGN AND REFORM IN CHILE}

Since the debut of the modern presidential regime in 1925, Chile has had three different electoral systems. Table 1 shows how they are different according to some of their core elements. Note that because of their lifespan, each was used for different number of times. While the first was used in 12 lower chamber elections, the second was used in seven. The third debuted in 2015 and has only been used once as of this time. What all these electoral systems have in common is the use of the d'Hondt proportional representation electoral formula. Yet, other than that, they are generally different. Clearly, the most permissive of the three is the first, followed by the last. This is no coincidence, since the last was inspired by the first (Gamboa and Morales 2016). 
Table 1. Electoral systems in Chile since 1925 (Lower Chamber)

\begin{tabular}{|l|c|c|c|}
\hline & $\begin{array}{c}\text { (1st) } \\
\mathbf{1 9 2 5 - 1 9 7 3}\end{array}$ & $\begin{array}{c}\text { (2nd) } \\
\mathbf{1 9 8 9 - 2 0 1 5}\end{array}$ & $\begin{array}{c}\text { (3rd) } \\
\text { Since 2015 }\end{array}$ \\
\hline District Magnitude (Min/Max) & $4.7 / 5.4$ & $2 / 2$ & $3 / 8$ \\
\hline District Magnitude (Average) & 5.1 & 2 & 5.5 \\
\hline Assembly Size (Min/Max) & $132 / 150$ & 120 & 155 \\
\hline Assembly Size (Average) & 145.8 & 120 & 155 \\
\hline Electoral Formula & d'Hondt & d'Hondt & d'Hondt \\
\hline Minimum Threshold & No & Yes & Yes \\
\hline
\end{tabular}

Source: Author.

\section{The binomial electoral system}

The electoral system in place from 1989 until 2015 was designed by the authoritarian government of Augusto Pinochet. It was devised with two major purposes in mind (see a detailed account in Pastor 2004). The first was to restrict the entrance of new parties into the political arena. This objective was grounded in the notion that the party system fragmentation of the 1970s was indirectly responsible for the breakdown of democracy (Valenzuela 1978). And since the proportional representation system in place at the time was syndicated as the main determinant of the fragmentation (Parrish et al. 1970; Sigmund 1977; Scully 1992), a permissive electoral system, such as the one that debuted in 1925, was promptly discarded as a feasible arrangement.

The second purpose was to boost the electoral results of the pro-authoritarian parties. In other words, overcompensate right-wing parties in the translation of votes to seats. This objective was buttressed in the idea that the authoritarian government would lose by an important margin of votes in the first election following transition (Rojas and Navia 2005). This was what insider-access to constituency-level results of the 1980 referendum, and international polls of the day, suggested (Valenzuela and Constable 1988). Indeed, by the end of the eighties, anti-dictatorship sentiment was on the rise, which significantly benefited parties that 
had taken a stand against the regime. Thus, a restrictive electoral system, such as a winnertake-all arrangement, was also rejected a priori.

A series of commissions were formed to work within these guidelines (Navia 2004). As suggested above, the designers knew that they could not adopt a proportional representation system that would incentive fragmentation, but they also knew they could not embrace a majoritarian system that would mechanically favor center-left parties. The designers ultimately proposed a proportional representation electoral system with the lowest possible district magnitude. Theoretically, this would work to both reduce the size of the party system and overrepresent the designers' commissioning party. Between 1980 and 1988 a series of drafts were drawn, and after the final amendments were made just months before the 1989 presidential and legislative election, a new electoral law was enacted.

The binomial system, as it later came to be known, included an important revision to the assembly size as well as to the district magnitude. As 13 seats were scrapped from the Senate, and 30 seats were eliminated from the Chamber of Deputies, district boundaries were redrawn across the board.i Because each district was assigned two seats, the average district magnitude fell to 2 from approximately 5. While the electoral formula did not change, and votes were to be translated to seats through the d'Hondt allocation method, the new law allowed for parties to form coalitions and compete in national (as opposed to local) electoral alliances in each district. Independents were also allowed to compete, but their votes were to be tallied in individual lists.

As will be explained below, the designers were generally successful in reaching their objective. The party system saw a sharp reduction in the number of electoral lists gaining legislative representation. The multiparty system of the pre-dictatorship democracy was reduced to a de facto two-party system (Jones and Mainwaring 2003: 156-157). The designers were also able to secure seats for the pro-dictatorship parties, that would have been impossible to obtain under any other arrangement (Siavelis 1997). The trade-off, however, was that their main rival (the pro-democracy parties) were also overrepresented. With none 
of the two coalitions able to obtain a significant legislative majority, the binomial produced a stable two-party system that would last for two decades.

\section{Between electoral systems}

As a direct result of the binomial system, party competition patterns consolidated between two electoral blocs. On one side, the anti-Pinochet left-leaning parties (henceforth, the traditional left) and on the other side the pro-Pinochet right-leaning parties (henceforth, the Alianza).ii The traditional left was able to elect four successive presidents (to serve between 1990 and 2010) before the Alianza was able to elect their first (that served between 2010 and 2014). And, because the traditional left and the Alianza were overrepresented in the legislature, at the cost of third parties, together they were able to dominate the national political agenda. While governing coalitions were normally able to impose their programs, they were rarely able to unilaterally pass major reform of their liking.

An example of this balance of power can be seen in the Constitutional negotiations of 2005, when both coalitions agreed to make substantial changes to the laws regulating elections (see detailed account in Fuentes 2015). Prompted by a campaign financing scandal, the reforms were set to take place at any cost. But, because of the opposing interests of each of the coalitions, the results ended in a tradeoff. While all designated seats were eliminated from the Senate (as the traditional left sought), the legislative quorum to conduct further electoral reform was raised to three-fifths from four-sevenths (as the Alianza imposed). Thus, while the legislature became somewhat more proportional to the vote distribution, the probability of making further electoral amendments to the electoral system decreased.

In retrospect, however, it is apparent that the result of these negotiations marked a tipping point. As the traditional left elected their fourth successive president in the 2006 presidential election, the Alianza began to make significant gains in public opinion polls. And only four years after the reform, they were able to elect their first presidential candidate to power. While this was a severe loss for the coalition that dominated elections for the two decades prior, it also served as a catalyst for them to rearticulate. As a backlash to the success of the 
Alianza, the traditional left expanded their coalition to include the Communist Party and occupy the full continuum of political supply from the center leftwards. With this new lineup, the traditional left embarked on a pathway back to power.

As part of their 2013 manifesto, they offered to conduct major electoral reform. However, because the quorum had been raised to three-fifths, this implied that they would have to win the next legislative election with a greater margin than in any of the previous elections. While they did win the election, they fell short of the sought majority. When the new legislative cohort was inaugurated in 2014, the traditional left debuted with two senators and seven deputies short of the majority required to undertake electoral reform unilaterally. Nonetheless, the new government decided to keep good on its promise. They commissioned a designer and began to draft the proposal. Their expectation was that they would eventually sway incumbent legislators into supporting the bill when the time came.

\section{The return to proportional representation}

The traditional left government coalition had two objectives in mind when it first approached the electoral designer (see a detailed account in Gamboa and Morales 2016). First, to increase the level of representation of the political system. Because the binomial system had served to reduce the number of parties, it excluded many groups of voters from gaining representation. As explained above, the reductive nature of the binomial system left electoral alliances that obtained up to twenty percent of the vote out of the competition. Thus, it was rapidly agreed upon that the new electoral reform would have to retrace its steps, and work towards a more proportional arrangement, where parties with lower vote shares could gain representation without facing the penalties of the binominal.

The second objective, related to the above, was precisely to produce more proportional electoral results. Here too, the idea was to reverse the distortion created by the binominal system designers. Indeed, the thought was that if more permissive incentives were to be introduced into the electoral law, the mechanical benefit in favor of the Alianza would be reversed. Precisely because more parties would be able to compete in elections, and most 
parties were left of center on the ideological spectrum, the electoral spoils would accumulate in their favor. Thus, with evidence of the fragmentation of the 1925-1973 system, the designers focused on the idea of reversing the biases of the binomial system by increasing the size of the assembly and the average district magnitude.

The designers worked within these guidelines to draft their proposal. They worked with greater technical freedom than the authoritarian designers, since permissiveness could only be gained in one direction. However, unlike the authoritarian designers they had to propose an alternative which would appeal to veto players in Congress. They ultimately settled on a PR-system similar to the one that debuted in 1925. Nonetheless, their original proposal was significantly watered down in Congress after it was first presented, to accommodate the interests of incumbents, especially those of their own coalition (Gamboa and Morales 2016: 130-133). For example, district boundaries were drawn to favor the reelection of sitting legislators, and not necessarily to increase levels of representation or proportionality.iii

As disused below, the designers were only partially successful in reaching their objective. While they did manage to increase the number of electoral lists gaining legislative representation, they did so at the cost of their commissioning party. The two-party system became further fragmented, but only left of center (Bunker 2018). As the traditional left suffered its worst electoral defeat ever in 2017 (the debut of the PR-system), new coalitions came to the forefront. Indeed, the loss of the traditional left was proportional to the gain of third parties. And, while the system became more proportional overall, it did not negatively affect the Alianza as expected. Remarkably, the right-wing coalition actually increased their advantage in the votes to seats ratio, obtaining their most important victory since 1989.

\section{Overall balance of electoral design and reform in Chile}

Before discussing the particular impact of each of the reforms, it is important to take a look at their overall effect. This retrospective approach can help identify the motivations behind the designers, beyond what has already been advanced in other case studies (e.g., Pastor 2004; Gamboa and Morales 2016). In this line, an important question that begs to be 
answered is in reference to the degree to which each of these reforms were made from a rational choice or an institutionalist perspective. While the literature discussed above seems to point to the fact that both the authoritarian and democratic designers expected that their own parties would be benefitted by their respective creations, it is unclear if they sought electoral spoils as a primary or a secondary effect.

An initial assessment can be made by comparing each of the reforms in terms of their deviation from standard expectations (set by cross-national trends). For example, if a reform adjusts to the standard, then it is likely that the designers were simply seeking to correct for underlying distortions (in line with the institutionalist approach). However, if a reform deviates from the standard, it is instead likely that the designers were seeking to generate an effect in a specific direction (in line with the rational choice approach). Furthermore, if the specific direction is consistent with the interests of the designers' party, it is likely that the designers were indeed putting their party's interests at the forefront (seeking electoral spoils as a primary effect).

To make this initial assessment, one core feature of electoral systems stands at the forefront: the size of the assembly. Since some have argued that assembly size is the most relevant determinant of electoral systems (see Taagepera 1972), reforms can be compared in terms of their deviations from the trend. To do so, the cube root law is useful,iv since it has been found to accurately predict assembly sizes when electoral systems are originally designed (Taagepera and Shugart 1989). And while it is true that it has been found to underestimate the assembly size in future modifications, only a handful of democracies have fallen outside the prediction (see Shugart and Taagepera 2017). Interestingly, Chile is one of these cases, presenting some of the highest deviations of all democracies (see Shugart 2014a).

Figure 1 plots this trend (on a logarithmic scale) and shows the direction and intensity of the deviations. While the first major electoral reform (1925) fell within the prediction, subsequent reforms (1989 and 2017) significantly deviated from it. Furthermore, the opposing shifts suggest that the designers sought opposite objectives. While the authoritarian designers sought to favor their party by reducing the size of the assembly (as the population 
approached 13 million), the democratic designers sought to favor their party by increasing it (as the population approached 18 million). Thus, while the institutionalist approach seems to be the most appropriate to frame the first electoral reform, the rational choice approach seems to be more appropriate to frame both the second and third ones.

\section{Figure 1. Predicting the Assembly Size in Chile, 1989-2017}

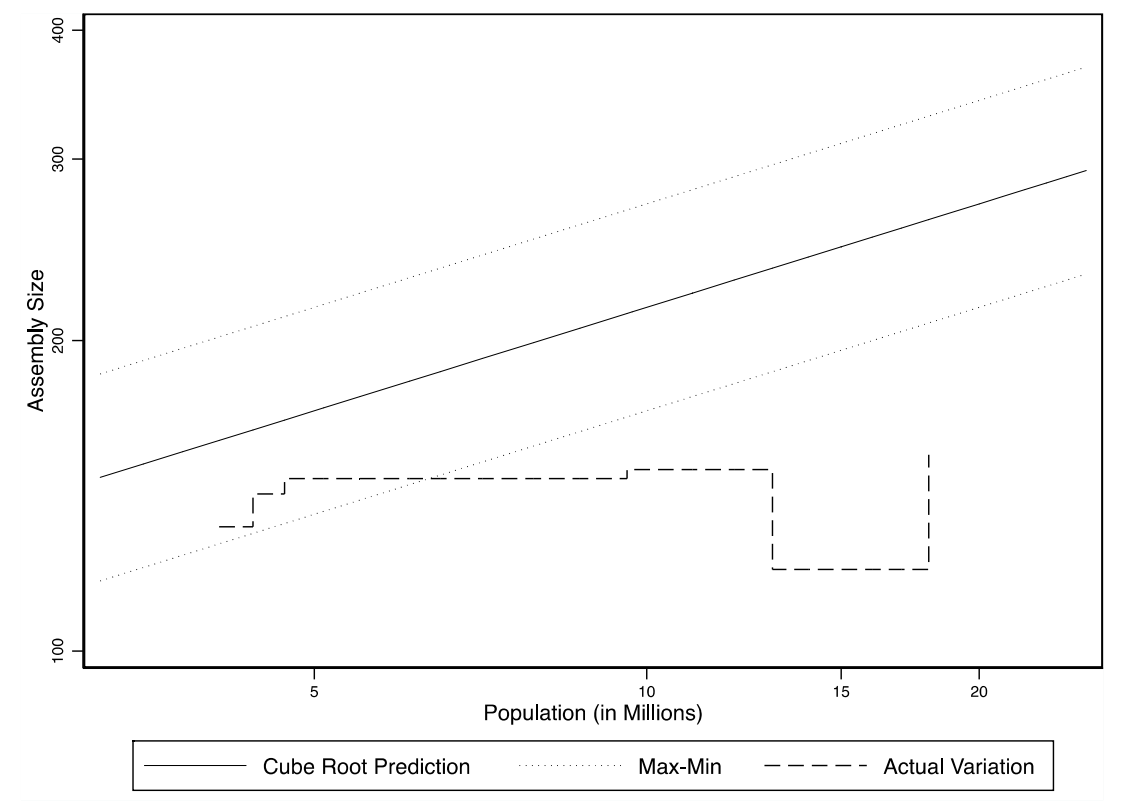

Source: Author.

The idea that both designers acted in favor of their parties is consistent with previous accounts (see Pastor 2004; Gamboa and Morales 2016). While this it is clear in the case of the former, there is also strong evidence in the case of the latter.v While it can be argued that the democratic designers were seeking a more fair and just system, which is likely, it can also be argued that doing so would have implicitly benefited their commissioner. Building on this idea, the next section shows that all of the evidence available before the reform pointed to the fact that, in the context of the stable party system, any increment in representation and proportionality would benefit the traditional left. Hence, the designers would not have been wrong to assume that their party would be the main beneficiaries of the reform. 


\section{HOW ELECTORAL DESIGNERS FAIL}

Departing from the idea that both the authoritarian and democratic designers sought to make electoral gains for their respective parties, this section discusses the effects of each of the electoral reforms by looking at the resulting patterns of representation and proportionality. First, it looks at variations in the size of the party system. It shows that while both designers were successful in creating shifts in their desired directions, the Alianza gained more than the traditional left by the collapse, and then the expansion, of the party system. Under the binominal, they obtained more seats than they would have obtained under any other arrangement. And more interestingly, under the PR-system, they actually increased their relative advantage.

The specific spoils in favor of the Alianza are visible in the patterns of proportionality. By looking at the translation of votes to seats in the elections following each of the reforms, this section shows that while both designers were effective in generating restrictive and permissive incentives, respectively, the pro-democracy traditional left-wing parties suffered the greatest costs. While the binomial electoral system benefited both major coalitions, it was biased in favor of the Alianza. And while the PR-system was expected to favor the traditional left, it actually worked in the opposite direction. Moreover, not only did the proportional representation system strengthen right-wing parties, but it also set traditional left-wing parties substantially back in their share of votes and seats.

\section{Variations in the size of the party system}

Figure 2 shows variations in the size of the party system from 1925 to 2018. It distinguishes between the effective number of electoral parties (ENEP) and the effective number of legislative parties (ENLP).vi Two observations are worth noting. First, that following the debut of the binomial electoral system, the number of parties did not decrease, as some scholars have argued (Guzman 1993; Rabkin 1996). Instead, the three-way party system, that marked the 1960s and 1970s, shifted into a significantly larger one. As Figure 3 suggests, however, the binomial effects did not operate at the party-level, but instead at the coalition- 
level, as others have noted (Siavelis 1997; Baldez and Carey 1999). Yet, while coalitions became the norm, parties did not cease to exist (Jones and Mainwaring 2003: 156-157).

Figure 2 also shows that following the 2015 reform, the party system expanded to its largest size in over half a century.vii Excluding the anomalous 1953 election, the 2017 election produced the most fragmented party system in the history of Chile. While more than ten parties competed in that year's lower chamber election, more than seven of them won seats. This observation alone suggests that the designer was indeed successful in producing a more representative outcome. This can be explained through a long-term approach. Parties maintained their independence because they anticipated that upon the abolishment of the binominal, party competition patterns would return to those of pre-authoritarian Chile, and as such, they would be able to independently resurface (see Siavelis 2005).

Figure 2. Number of parties, 1925-2017

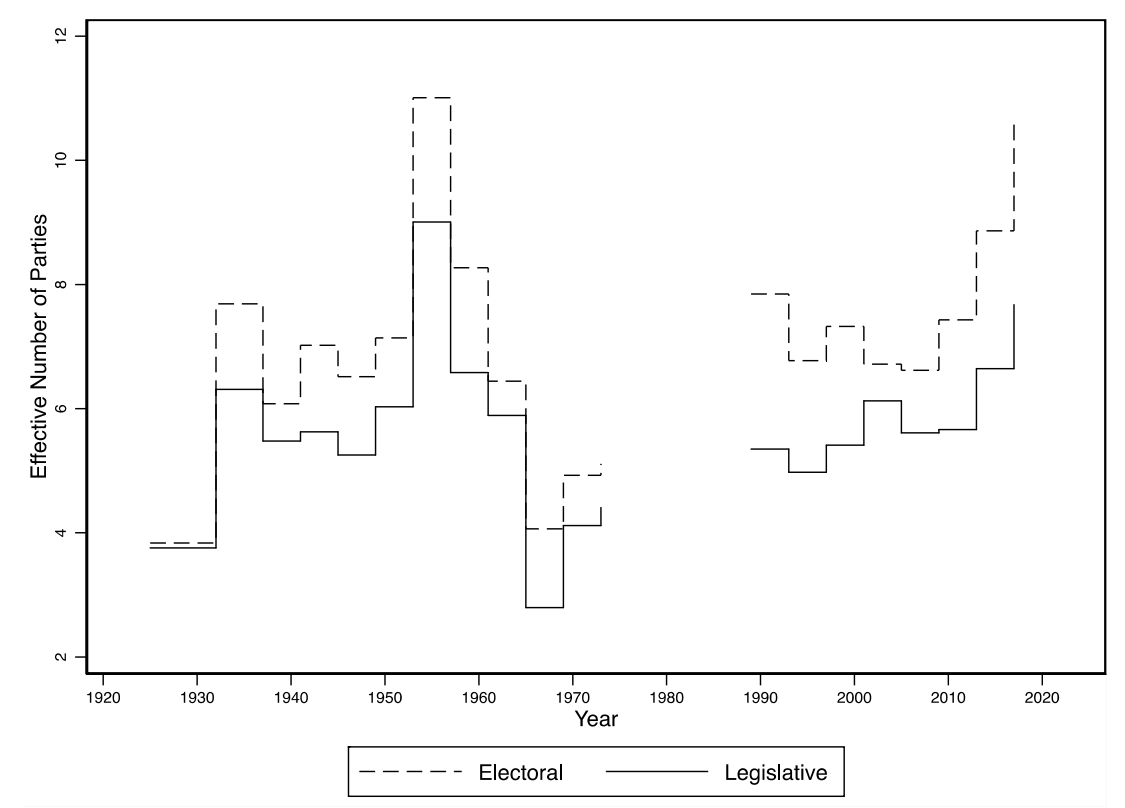

Source: Author.

While the number of electoral coalitions increased over time, the number of winning coalitions remained relatively stable. Even though parties formed new coalitions, they were rarely successful. In the six legislative elections that took place between 1989 and 2009, only 
the Alianza and the traditional left were able to win seats. It was only in 2013 that a third coalition was able to enter the legislature, when a candidate from the Partido Liberal was elected in the northern-most district.viii In 2017, the number of third parties further increased, when in addition to the preexisting distribution, the Frente Amplio and the Christian Democrats won seats as individual coalitions. It is important to note, however, that all three of these lists won seats on left or center-left platforms.

So, considering the increase in the number of parties and the rise of coalitional competition, how effective was the binominal system designer in reducing the size of the party system? Figure 3 uses the seat-product model (SPM) as a standard to answer this question.ix The solid line represents the number of expected coalitions; and the dashed lines show the number of vote-winning coalitions and the number of seat-winning coalitions. The trend suggests that the authoritarian electoral designers were indeed successful, since they were largely able to maintain the number of seat-winning coalitions below the SPM prediction. The binominal system worked efficiently to keep the number of legislative coalitions significantly lower than the number of electoral coalitions.

Figure 3. Number of coalitions, 1989-2017

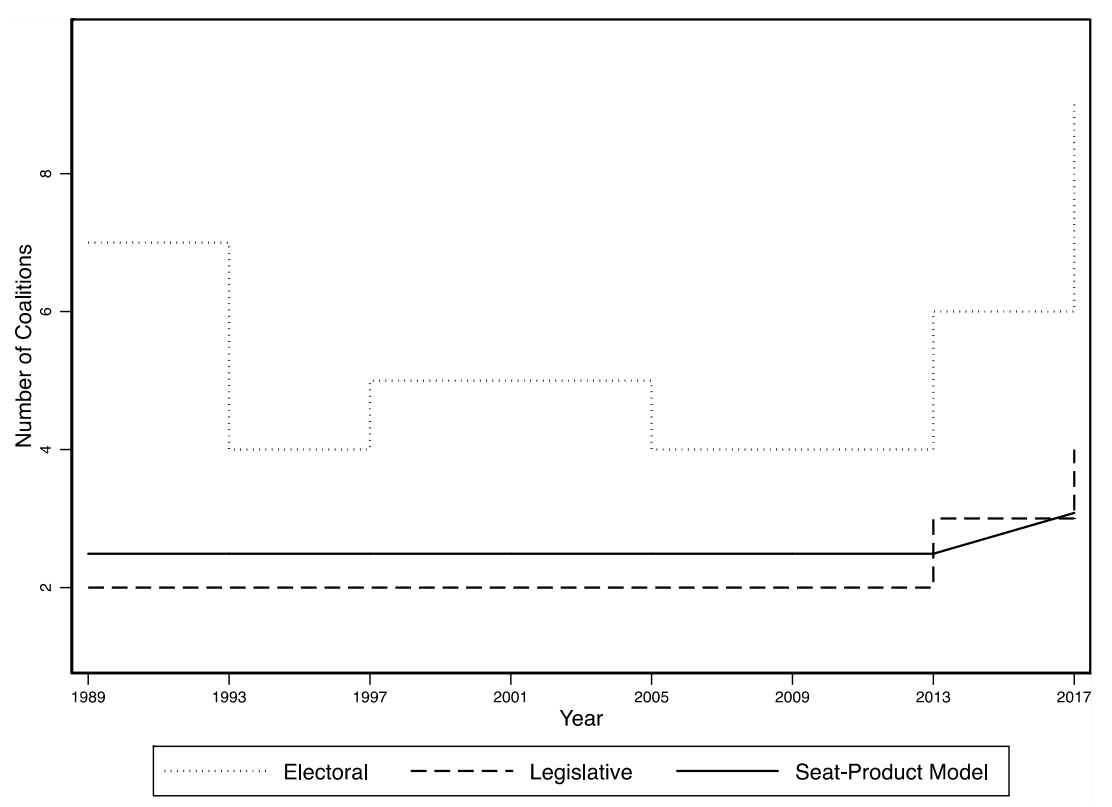

Source: Author. 
However, what is most interesting in Figure 3 is the intersection of the SPM prediction with the number of seat-winning coalitions, circa 2013.x The intersection seems out of place considering that at that time there had been no changes to the assembly size, the district magnitude or any other core elements of the electoral system. Thus, one could argue that the pre-reform fragmentation occurred due to an unusual increase in social heterogeneity. However, there is no evidence of that. Instead, it seems more likely that parties (at least partially) reacted to the reform announced by the traditional left 2013 presidential campaign (of Bachelet). This account is consistent with Benoit's (2002) argument that parties respond "psychologically" to electoral reforms before they even occur.

It is important to note, however, that the pattern of fragmentation that began around the 2013 election was not normally distributed throughout the ideological spectrum. While the number of coalitions did indeed increase in 2013, it was only in the left (and marginal at the legislative level, as mentioned above). The only coalition that competed on a right-wing platform that year was the Alianza. All other coalitions competed on left, liberal or progressive platforms (see Bunker 2014). In this sense, it was left of center parties that implicitly anticipated the new electoral system and the spoils they could secure if a more proportional electoral system were adopted. At the same time, it is also likely that the expanding party system put further pressure on the elected government to conduct electoral reform.

Before showing how exactly the third electoral system impacted the electoral spoils of the traditional left (which commissioned the reform), it is important to show its effects on the party system as a whole. Table 2 shows two logistic regressions (with robust standard errors), using electoral results for all lower chamber candidates (a total of 1,429 individuals) in the two elections that took place around the 2015 electoral reform (2013 and 2017). The dependent variable is whether an individual candidate was elected (yes $=1 / \mathrm{no}=0$ ) and the independent variable is whether that candidate belonged to a traditional coalition (yes $=1 /$ no $=0$ ). The results clearly show that the probability of being elected on the ticket of a traditional coalition significantly declined after the reform. 
Table 2. Explaining electoral success, 2013 and 2017

\begin{tabular}{|l|c|c|c|c|}
\hline & \multicolumn{2}{|c|}{2013} & \multicolumn{2}{c|}{$\mathbf{2 0 1 7}$} \\
\hline & coef. & s.e. & coef. & s.e. \\
\hline Traditional Coalition & $2.86^{* * *}$ & 0.30 & $1.90^{* * *}$ & 0.20 \\
\hline (alfa) & $-2.81^{* * *}$ & 0.27 & $-2.64^{* * *}$ & 0.16 \\
\hline N (candidates) & \multicolumn{2}{|c|}{470} & \multicolumn{2}{c|}{959} \\
\hline Pseudo r2 & \multicolumn{2}{|c|}{0.252} & 0.124 \\
\hline Correctly classified & \multicolumn{2}{|c|}{$75.53 \%$} & $83.84 \%$ \\
\hline McFadden r2 (adj) & 0.245 & 0.120 \\
\hline Nagelkerke r2 & 0.367 & 0.177 \\
\hline
\end{tabular}

Source: Author. Significance: $* * *: p<0.01$.

\section{Shifts in electoral proportionality}

To explore the particular effects generated by both electoral reforms, this subsection looks at general patterns of proportionality. Table 3 shows the difference between the percentage of votes and the percentage of seats between 1989 and 2017. It shows that under both electoral systems the Alianza was the most benefited coalition, always obtaining more seats than strictly proportional. While the traditional left was also benefitted, the spoils for the Alianza were always significantly greater, especially under the new PR-system - in which they were overrepresented by $8.4 \%$. This lends partial support to the idea that the traditional left was under the impression that a more representative and proportional system (such as the one adopted in 2015) would benefit them over their main competitor.

Table 3. Difference between votes and seats, 1989-2017

\begin{tabular}{|l|c|c|c|c|c|c|c|c|c|}
\hline & \multicolumn{3}{|c|}{ Alianza } & \multicolumn{3}{c|}{ Traditional Left } & \multicolumn{3}{c|}{ Others } \\
\hline & \% V & \% S & dif. & \% V & \% S & dif. & \% V & \% S & dif. \\
\hline 1989 & 34.2 & 40.0 & 5.8 & 51.5 & 57.5 & 6.0 & 14.3 & 2.5 & -11.8 \\
\hline 1993 & 36.7 & 41.6 & 4.9 & 55.4 & 58.3 & 2.9 & 7.9 & 0.1 & -7.8 \\
\hline 1997 & 36.3 & 39.2 & 2.9 & 50.5 & 57.5 & 7.0 & 13.2 & 3.3 & -9.9 \\
\hline
\end{tabular}




\begin{tabular}{|l|l|l|l|l|l|l|l|l|l|}
\hline 2001 & 44.3 & 47.5 & 3.2 & 48.0 & 51.7 & 3.7 & 7.7 & 0.8 & -6.9 \\
\hline 2005 & 38.7 & 45.0 & 6.3 & 51.8 & 54.2 & 2.4 & 9.5 & 0.8 & -8.7 \\
\hline 2009 & 43.5 & 48.3 & 4.9 & 44.4 & 47.5 & 3.2 & 12.1 & 4.2 & -7.9 \\
\hline 2013 & 36.2 & 40.8 & 4.6 & 47.7 & 55.8 & 8.1 & 16.1 & 3.4 & -12.7 \\
\hline 2017 & 38.7 & 47.1 & 8.4 & 34.7 & 36.1 & 1.4 & 26.6 & 16.8 & -9.8 \\
\hline Average & $\mathbf{3 8 . 6}$ & $\mathbf{4 3 . 7}$ & $\mathbf{5 . 1}$ & $\mathbf{4 8 . 0}$ & $\mathbf{5 2 . 3}$ & $\mathbf{4 . 3}$ & $\mathbf{1 3 . 4}$ & $\mathbf{4 . 0}$ & $\mathbf{- 9 . 4}$ \\
\hline
\end{tabular}

Source: Author.

Figure 4 plots the results of lower chamber elections between 1989 and 2017 for the Alianza, the traditional left, and third parties. It differentiates between vote shares (left plot) and seat shares (right plot). It shows that while the Alianza advanced from about 35 to 40 percent of the votes, the traditional left fell from around 50 percent to 35 percent. At the same time, third parties advanced from about 12 percent to 25 percent. Remarkably, the sharpest downfall for the traditional left occurred in the 2017 election, after the 2015 electoral reform. Indeed, the worst electoral results for the traditional left in post-Pinochet Chile were not under the binomial system, but under the PR-system. This suggests that the designers' idea that a more proportional arrangement would benefit their party was wrong.

Figure 4. Electoral results in the lower chamber, 1989-2017

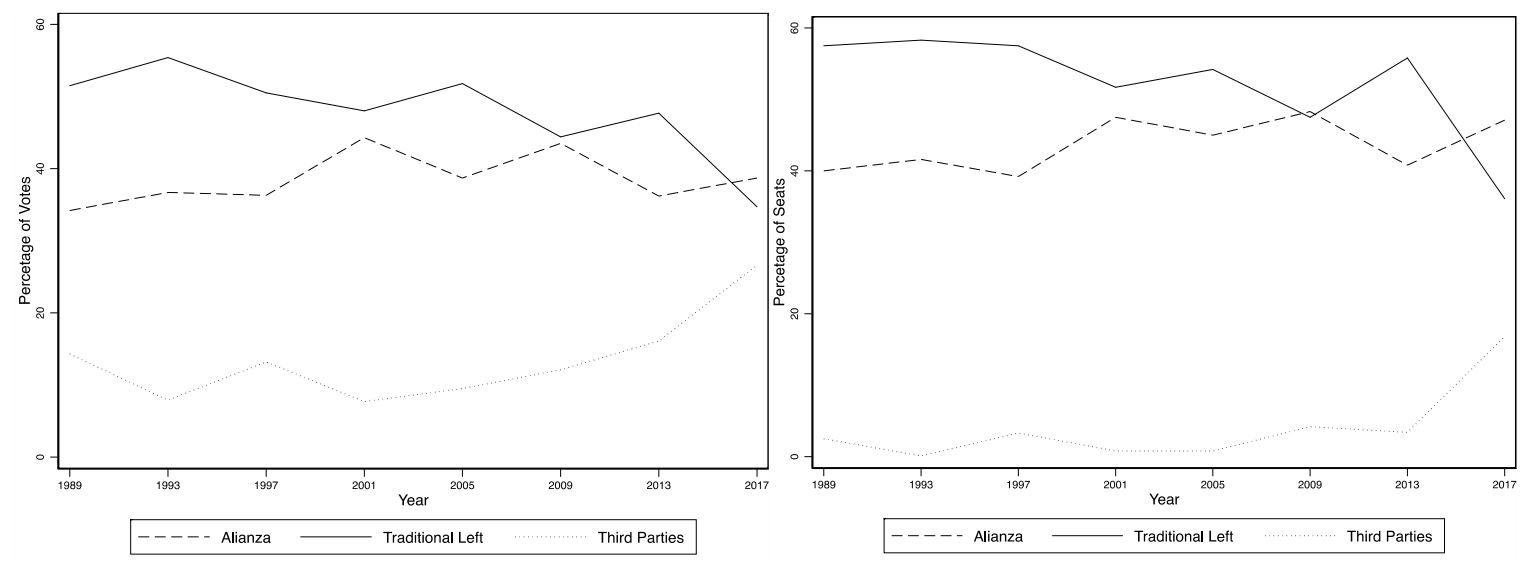

Source: Author. 
Table 4 uses electoral input (votes) and electoral return (seats) for the Alianza and third parties to explain the variation of vote and seat shares of the traditional left. It shows two OLS regressions (with robust standard errors), using electoral results for all eight lower chamber elections between 1989 and 2017.xi It confirms the trend suggested above. The decline of the traditional left is largely due to the rise of third parties. Indeed, the proportion of variation in the share of votes and seats for the traditional left is better explained by the rise of third parties than by the electoral gains of the Alianza. While the proportion of the variation in the traditional left's vote share is explained in $69 \%$ by the vote share for third parties, it is explained in $11 \%$ by the vote share for the Alianza (and is not even significant).

Table 4. Explaining the decline of the traditional left, 1989-2017

\begin{tabular}{|l|c|c|c|c|c|c|c|c|}
\hline & \multicolumn{4}{|c|}{ Votes } & \multicolumn{3}{c|}{ Seats } \\
\hline & coef. & s.e. & coef. & s.e. & coef. & s.e. & coef. & s.e. \\
\hline Alianza & -.59 & .30 & & & $-1.49 * *$ & .54 & & \\
\hline Third Parties & & & $-.86 * * *$ & .19 & & & $-1.23 * * *$ & .11 \\
\hline$($ alfa $)$ & 70.6 & 11.9 & $59.5 * * *$ & 3.20 & $117.4 * * *$ & 22. & $57.2 * * *$ & 1.6 \\
\hline N (elections) & \multicolumn{2}{|c|}{8} & \multicolumn{2}{|c|}{8} & \multicolumn{2}{|c|}{8} & 8 \\
\hline R-squared & .112 & \multicolumn{2}{|c|}{.693} & .541 & .784 \\
\hline Prob > F & 0.101 & \multicolumn{2}{|c|}{.004} & 7.53 & 134.9 \\
\hline Root MSE & 6.410 & \multicolumn{2}{|c|}{3.768} & \multicolumn{2}{|c|}{5.474} & 3.760 \\
\hline
\end{tabular}

Source: Author. Significance: $* * *: \mathrm{p}<0.01 ; * *: \mathrm{p}<0.05$.

Of course, the decline of the traditional left cannot merely be explained by the rise of third parties, since they only reacted to endogenous variations within the party system. It can also be explained by the unwavering unity of the Alianza, which stood together in all elections disputed since the transition to democracy. At the same time, the cohesion of the Alianza cannot be understood without taking into account the systematic spoils they received from the binominal system. Figure 5 shows the magnitude of their advantage. Following Shugart (2014b), it suggests that under the binomial system the vote share was oddly and inversely 
correlated to the seats-to-votes ratio.xii Remarkably, as the vote percentage in favor of the traditional left increased, the seats-to-votes ratio in favor of the Alianza increased.

\section{Figure 5. Advantage of the Alianza under the binomial electoral system}

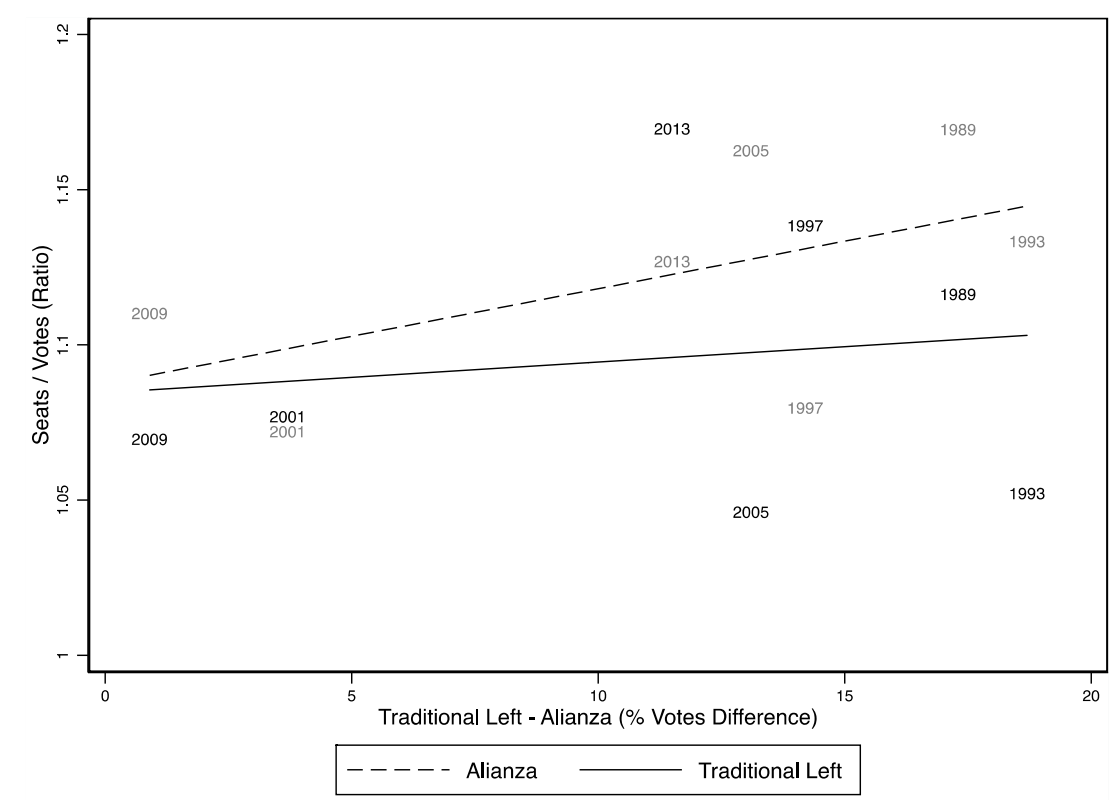

Source: Author. Note: Years in gray correspond to the Alianza; years in black correspond to the Traditional Left.

\section{DISCUSSION}

The nature of each of the two electoral reforms suggest that the designers acted from a rational choice perspective, with the thought of benefiting their commissioning parties in mind. There is vast evidence to uphold this idea in the case of the authoritarian reform, as well as strong support to establish the same in the case of the democratic one. However, evidence shows that while the first designers were successful in their objective, the second ones were not. We know this because the Alianza was benefitted both under both the binominal system and the PR-system, whilst the traditional left was only able to partially benefit from the former. Indeed, far from the democratic designers' expectations, the PRsystem led the traditional left to lose significant ground. 
As mentioned above, electoral institutions do not operate exclusively on party system order, but instead in interaction with social structures and electoral strategies that parties respond to and implement in order to face elections. In this sense, the defeat of the traditional left cannot be exclusively explained by the adoption of the PR-system. Rather, a more nuanced explanation, that involves the context in which the reform was designed and implemented, is warranted. In this vein, the anticipation of third parties to the electoral reform should be understood as the first indicator that traditional left would not be the sole beneficiary of the new electoral system. The designers could have read this initial fragmentation as a warning sign that the reform would come with an inevitable cost. It is unclear if they did.

What is clear, however, is that they decided to move forward anyway. The likely explanation, articulated here, is that once the announcement to enact electoral reform was put forward in the 2013 campaign, there was no turning back, especially as the reform became more viable. While the designers may have initially attempted to produce more representative and proportional results, they did so under the impression that it would ultimately benefit their commissioner. Once they realized that this would not necessarily be the case, there is at least partial evidence that they attempted to curtail costs; for example Gamboa and Morales (2016: 130-133) show that districts were redrawn in late stages of the negotiation in order to benefit incumbents associated to the commissioning party.

\section{CONCLUSION}

Electoral systems are created and revised under a variety of conditions. When commissioned with the engineering of a new arrangement, electoral designers are normally asked to work within certain frameworks. While they are free to explore alternatives, their scope of action is usually limited to options that do not hinder their commissioners. Indeed, rarely will an electoral reform take place if it can potentially set the ruling party back in its vote and seat share (Benoit 2004; Colomer 2004). As such, electoral designers can be evaluated in terms of the outcome they secure for their commissioners. Electoral designers that engineer a more democratic system, with higher levels of representation and proportionality, cannot possibly be considered successful if their arrangement leads to the downfall of their party. 
This article has looked at two reforms made in Chile within the span of thirty years. Because both designers manipulated the same core elements - assembly size and district magnitudethey can be compared to each other. And because the designers had political objectives in mind when they engineered their respective arrangements, they can be contrasted in terms of their effectivity. The results are apparent. While one was successful, the others were not. The first designers secured electoral spoils for their party that would have been impossible to obtain under any other system. The second designers proposed a system that would subsequently lead to the worst electoral result in the recent history of their commissioning party.

This article suggests a benchmark by which electoral designers can be evaluated. Because the results of elections can be contrasted over time, designers can be compared to each other. With standards such as the cube root law and the seat product model, the results of elections following the application of the new arrangements can be used to explain their levels of success. In the case of Chile, this article has shown that while some designers were remarkably successful in guaranteeing the overrepresentation of their parties (by adopting a restrictive electoral system), the others failed to do the same (by adopting permissive electoral rules). By not accounting for the fact that party fragmentation would only occur on one side of the ideological continuum, they directly hindered their commissioning party.

This article has used Chile to show how designers can be evaluated and illustrated the contexts under which they can fail to produce an outcome in favor of their commissioner. It has shown that because the democratic designer sought to introduce permissive elements into the incumbent set of rules, they hindered their commissioning party. At the same time, it has argued that the reform per se was not responsible for the loss. Instead, it was the context under which it was conducted. In contrast to the authoritarian designers, the democratic ones were restricted by contextual straitjackets, and as such were forced to engineer their arrangement amidst the shifting party system. Unable or unwilling to take into account the inertia of the political landscape, they failed to produce spoils in favor of their commissioner. 
The findings in this article should be considered in the light of the evidence. While one electoral system analyzed in this study (the binomial) was used for seven elections (19892013), the other one (the PR-system) was used for one election (2017). Thus, it is possible that trends related to the latter could shift in the future. At any rate, any deviations from the norm could provide an opportunity for future research to delve further into the consequences of electoral system design and reform. Indeed, if an electoral system adopted in democracy is not amended after its debut, yet produces unpredictable results over time, the standards under which electoral reformers are evaluated should be extended to include equilibrium as a central consideration. 


\section{REFERENCES}

Andrews, Josephine T., and Robert W. Jackman. 2005. "Strategic fools: Electoral rule choice under extreme uncertainty." Electoral Studies 24(1): 65-84.

Argersinger, Peter H. 1980. "A place on the ballot: Fusion politics and antifusion laws." The American Historical Review 85(2): 287-306.

Baldini, Gianfranco. 2011. "The different trajectories of Italian electoral reforms." West European Politics 34(3): 644-663.

Baldez, Lisa, and John M. Carey. 1999. "Presidential agenda control and spending policy: Lessons from general Pinochet's constitution." American Journal of Political Science 43(1): 29-55.

Benoit, Kenneth. 2004 "Models of electoral system change.” Electoral Studies 23(3): 363389.

Blais, Andre, and Matthew S. Shugart. 2008. "Conclusion.” In To keep or to change first past the post? The politics of electoral reform, edited by Andre Blais. Oxford: Oxford University Press, 184-207.

Blau, Adrian. 2008. "Electoral reform in the UK: A veto player analysis." In To keep or to change first past the post? The politics of electoral reform, edited by Andre Blais. Oxford: Oxford University Press, 61-89.

Boix, Carles. 1999. "Setting the Rules of the Game: The Choice of Electoral Systems in Advanced Democracies.” American Political Science Review 93(3): 609-24.

Bowler, Shaun, and Todd Donovan. 2013. The limits of electoral reform. Oxford: Oxford University Press. 
Bunker, Kenneth. 2014. "The 2013 presidential and legislative elections in Chile." Electoral Studies 33(4): 346-348.

Bunker, Kenneth. 2018. "La elección de 2017 y el fraccionamiento del sistema de partidos en Chile." Revista de Derecho y Ciencia Política 9(2): 204-229.

Cain, Bruce E. 1985. "Assessing the partisan effects of redistricting." American Political Science Review 79(2): 320-333.

Carey, John M. 1998. Term limits and legislative representation. New York: Cambridge University Press.

Clark, William R., and Matt Golder. 2006. "Rehabilitating Duverger's theory: Testing the mechanical and strategic modifying effects of electoral laws." Comparative Political Studies 39(6): 679-708.

Colomer, Josep M. 2004. Handbook of electoral system choice. Houndmills: Palgrave Macmillan.

Colomer, Josep M. 2005. 'It's parties that choose electoral systems (or, Duverger's laws upside down).” Political Studies 53(1): 1-21.

Cox, Gary W. 1997. Making votes count: Strategic coordination in the world's electoral systems. Cambridge: Cambridge University Press.

Robert, Dahl. 1971. Polyarchy: participation and opposition. New Haven: Yale University Press.

Duverger, Maurice. 1954. Political parties: Their organization and activity in the modern state. London: Methuen. 
Engstrom, Erik J., and Samuel Kernell. 2005. "Manufactured responsiveness: The impact of state electoral laws on unified party control of the presidency and House of Representatives, 1840-1940.” American Journal of Political Science 49(3): 531-549.

Freidenberg F, and Tomás Dosek. 2015. "Las reformas electorales en América Latina (1978-2015)." In Reformas Políticas en América Latina: Tendencias y casos, edited by Kevin Casas Zamora, Raquel Chanto, Betilde Muñoz-Pogossian and Marian Vidaurri. Washington, D.C.: Organización de los Estados Americanos, 25-92.

Fuentes, Claudio. 2015. "Shifting the status quo: Constitutional reforms in Chile." Latin American Politics and Society 57(1): 99-122.

Gamboa, Ricardo, and Mauricio Morales. 2016. "Chile's 2015 electoral reform: Changing the rules of the game." Latin American Politics and Society 58(4): 126-144.

Guzmán, Eugenio. 1993. "Reflexiones sobre el sistema binominal.” Estudios Públicos 51: 303-325.

Horowitz, Donald L. 1990. "Comparing democratic systems." Journal of Democracy 1(4): 73-79.

Jacobs, Kristof, and Simon Otjes. 2015. "Explaining the size of assemblies. A longitudinal analysis of the design and reform of assembly sizes in democracies around the world." Electoral Studies 40: 280-292.

Jones, Mark P. 1995. "A guide to the electoral systems of the Americas." Electoral Studies 14(1): 5-21.

Jones, Mark P. 1999. "Electoral laws and the effective number of candidates in presidential elections." The Journal of Politics 61(1): 171-184. 
Jones, Mark P., and Scott Mainwaring. 2003. "The nationalization of parties and party systems: An empirical measure and an application to the Americas." Party Politics 9(2): 139-166.

Leyenaar, Monique, and Reuven Y. Hazan. 2011. "Reconceptualising electoral reform." West European Politics 34(3): 437-455.

Lijphart, Arend. 1984. Democracies: Patterns of majoritarian and consensus government in twenty-one countries. New Haven: Yale University Press.

Lijphart, Arend. 1994. Electoral systems and party systems: A study of twenty-seven democracies, 1945-1990. New Haven: Yale University Press.

Lijphart, Arend, and Bernard Grofman. 1984. Choosing an electoral system: Issues and alternatives. New York: Praeger.

Mainwaring, Scott, and Matthew S. Shugart. 1997. "Conclusion: Presidentialism and the party system." In Presidentialism and democracy in Latin America, edited by Scott Mainwaring and Matthew S. Shugart. Cambridge: Cambridge University Press.

Magar, Eric, Marc R. Rosenblum, and David Samuels. 1998. "On the absence of centripetal incentives in double-member districts: The case of Chile." Comparative Political Studies 31(6): 714-739.

Masket, Seth E. 2007. "It takes an outsider: Extra legislative organization and partisanship in the California Assembly, 1849-2006.” American Journal of Political Science 51(3): 482497.

Navia, Patricio. 2004. "The 2-seat Proportional Representation Arrangement as an Insurance Mechanism against Defeats: What Can Risk-Averse Office Holders Do?” Department of Politics \& Center for Latin American and New York University. 
Navia, Patricio, and Priscilla Rojas. 2005. "Representación y tamaño de los distritos electorales en Chile, 1988-2002." Revista de Ciencia Política 25(2): 91-116.

Negretto, Gabriel L., and Giancarlo Visconti. 2018. "Electoral reform under limited party competition: The adoption of proportional representation in Latin America." Latin American Politics and Society 60(1): 27-51.

Neto, Octavio A., and Gary W. Cox. 1997. "Electoral institutions, cleavage structures, and the number of parties." American Journal of Political Science 41(1): 149-174.

Norris, Pippa. 1995. "Introduction: The politics of electoral reform.” International Political Science Review 16(1): 3-8.

Norris, Pippa. 1997. “Choosing electoral systems: Proportional, majoritarian and mixed systems.” International Political Science Review 18(3): 297-312.

Norris, Pippa. 2004. Electoral engineering: Voting rules and political behavior. Cambridge: Cambridge University Press.

Ordeshook, Peter C., and Olga V. Shvetsova. 1994. "Ethnic heterogeneity, district magnitude, and the number of parties." American Journal of Political Science 38(1): 100123.

Parrish, Charles J., Arpad J. Von Lazar, and Jorge I. Tapia-Videla. 1970. "Electoral procedures and political parties in Chile." Studies in Comparative International Development 6(12): 255-267.

Pastor, Daniel. 2004. "Origins of the Chilean binominal election system." Revista de Ciencia Política 24(1): 38-57. 
Przeworski, Adam. 1999. “'Minimalist Conception of Democracy: A Defense.’ In Democracy's Value, edited by Ian Shapiro and Casiano Hacker-Cordón. Cambridge: Cambridge University Press, 23-55.

Rabkin, Rhoda. 1996. "Redemocratization, electoral engineering, and party strategies in Chile, 1989-1995." Comparative Political Studies 29(3): 335-356.

Rae, Douglas W. 1967. The political consequences of electoral laws. New Haven: Yale University Press.

Rahat, Gideon. 2008. "Entering through the back door: Non-party actors in intra-party (s)electoral politics." In Competitors to parties in electoral politics: The rise of non-party actors, edited by David Farrell and Rudiger Schmitt-Beck. Baden: Nomos-Verlag, 25-44.

Remmer, Karen L. 2008. "The politics of institutional change: Electoral reform in Latin America, 1978-2002." Party Politics 14(1): 5-30.

Renwick, Alan. 2010. The politics of electoral reform: Changing the rules of democracy. Cambridge: Cambridge University Press.

Reynolds, Andrew, Ben Reilly, and Andrew Ellis. 2008. Electoral system design: The new international IDEA Handbook. Stockholm: International Institute for Democracy and Electoral Assistance.

Riker, William H. 1982. "The two-party system and Duverger's Law: An essay on the history of political science." American Political Science Review 76(4): 753-766.

Shugart, Matthew S. 2008. "Inherent and contingent factors in reform initiation in plurality systems." In To keep or to change first past the post? The politics of electoral reform, edited by Andre Blais. Oxford: Oxford University Press, 7-60. 
Shugart, Matthew S. 2014a, 7 of January. "Economix: Expand the US House." Recovered on 5 of January of 2020 from

https://fruitsandvotes.wordpress.com/category/electoral-rules/cube-root-law/

Shugart, Matthew S. 2014b, 2 of November. "Visualizing the impact of two-seat districts. Fruits and Votes.” Recovered on 5 of January of 2020 from https://fruitsandvotes.wordpress.com/2014/11/02/visualizing-the-impact-of-two-seatdistricts/

Shugart, Matthew S., and John M. Carey. 1992. Presidents and assemblies: Constitutional design and electoral dynamics. Cambridge: Cambridge University Press.

Shugart, Matthew S., and Martin P. Wattenberg (Eds). 2001. Mixed-member electoral systems: The best of both worlds? New York: Oxford University Press.

Shugart, Matthew S., and Rein Taagepera. 2017. Votes from seats: Logical models of electoral systems. Cambridge: Cambridge University Press.

Siavelis, Peter. 1997. "Continuity and change in the Chilean party system: On the transformational effects of electoral reform.” Comparative Political Studies 30(6): 651-674.

Siavelis, Peter. 2005. "Chile: The unexpected (and expected) consequences of electoral engineering." The politics of electoral systems, edited by Michael Gallagher and Paul Mitchell. Oxford: Oxford University Press, 433-52.

Sigmund, Paul E. 1977. The overthrow of Allende and the politics of Chile, 1964-1976. Pittsburgh: University of Pittsburgh Press.

Taagepera, Rein, and Bernard Grofman. 2003. "Mapping the indices of seats-votes disproportionality and inter-election volatility." Party Politics 9(6): 659-677. 
Taagepera, Rein, and Markku Laakso. 1980. "Proportionality profiles of West European electoral systems." European Journal of Political Research 8: 423-46

Taagepera, Rein, and Matthew S. Shugart. 1989. Seats and votes: The effects and determinants of electoral systems. New Haven: Yale University Press.

Teorell, Jan, and Catharina Lindstedt. 2010. "Measuring electoral systems." Political Research Quarterly 63(2): 434-448.

Valenzuela, Arturo. 1978. The breakdown of democratic regimes, Chile. Baltimore: Johns Hopkins University Press.

Valenzuela, Arturo, and Pamela Constable. 1988. "Plebiscite in Chile: End of the Pinochet Era?" Current History 87(525): 29.

Van der Kolk, Henk. 2007. "Electoral system change in the Netherlands: The road from PR to PR (1917-2006).” Representation 43(4): 271-287.

Vowles, Jack. 2008. "Systemic failure, coordination, and contingencies: understanding electoral system change in New Zealand." In To keep or to change first past the post? The politics of electoral reform, edited by Andre Blais. Oxford: Oxford University Press, 16383.

Winburn, Jonathan. 2008. The realities of redistricting: Following the rules and limiting gerrymandering in state legislative redistricting. Lanham: Lexington Books. 


\section{ENDNOTES}

i In addition to the 38 elected senators, the binomial system also provided for a variable number of designators senators, to be (mainly) appointed from the branches of the Armed Forces. The logic behind this provision was to prevent opposition parties from making further amendments to the law.

ii These labels are used for simplicity. The traditional left was mainly composed of the Partido Demócrata Cristiano (DC), Partido Socialista (PS), Partido Por la Democracia (PPD) and the Partido Radical (PR); the lineup only changed in 2013 when the Partido Comunista (PC) entered the coalition, and in 2017, when the PDC left the to compete on its own as an independent coalition. The traditional left mainly competed as the Concertación, and only changed names in 2013 to be called the Nueva Mayoría. The Alianza was mainly composed by the Unión Demócrata Independiente (UDI) and Renovación Nacional (RN). While the lineup changed to add or subtract a few parties over the years, the core and elite leadership remained largely unchanged. The Alianza changed names over years; in 2013 and 2017, for example, it competed as Chile Vamos.

iii Gamboa and Morales (2016) argue that to make the proposal more attractive for legislators of their own coalition, especially Christian Democrats, the district magnitude of all the new districts was increased by at least one (p. 130). They add that it is "well known that districts were drawn on political criteria" (p. 131). iv The cube-root model was proposed by Taagepera (1972). It is estimated by calculating the cube root of the population. Its margin of error is estimated by taking the cube root of the double of the population (Max.), and the cube root of half the population (Min.).

v One of Gamboa and Morales' (2016) central arguments is that the principal motivation behind the reform was to resolve internal political issues of the traditional left (which were presumably obstructing the pathway to making larger electoral gains), rather than to repair the electoral system for general interest purposes. While they accept that the reform did aim to increase representation and proportionality, these issues were not primary objectives (p. 143).

vi The effective number of parties was proposed by Markuu Laakso and Rein Taagepera (1979). It is estimated by dividing one by the sum of the square of the number of votes of each party, at either the electoral or legislative level.

vii The only election that produced a greater party system was the 1953 presidential and legislative election. However, this is considered an outlier year in Chilean politics. The president elected in 1953 was Carlos Ibáñez del Campo. The rise in the ENP was due to the appearance of a dozen small Ibañez-related parties, which were grouped into two different coalitions: the National People's Alliance and the National Federation of Ibañista Forces.

viii Vlado Mirosevic in Arica (District 1).

ix The Seat-Product model was proposed by Taagepera (2007) and developed by Shugart and Taagepera (2017). It is estimated by calculating the square root of the cube root of the multiplication of the assembly size and the average district magnitude.

$x$ Under the binomial system (1989-2013), the predicted number of coalitions was 2.5 (assembly size $=120 \mathrm{x}$ district magnitude=2). Under the PR-system (since 2017), the predicted number of coalitions was 3.1 (assembly size $=155$; district magnitude $=5.5$ ).

xi With the small sample size (8 elections), the results should be read with caution. As such it should be interpreted as correlation rather than causality.

xii Taagepera and Laakso (1980) suggest that the best way to visualize how electoral systems treat parties (or coalitions) is not by using the difference between seat and vote shares for each party, but by the advantage ratio. 